\title{
Vitamin A esterase activity in various organs of the chick
}

\author{
By I. NIR, I. BRUCKENTAL AND I. ASCARELLI \\ Department of Animal Nutrition and Agricultural Biochemistry, \\ Faculty of Agriculture, Hebrew University, Rehovot, Israel \\ (Received 20 September 1966-Accepted I4 February 1967)
}

\begin{abstract}
I. The distribution of vitamin A esterase activity for vitamin A acetate, palmitate, and alcohol was studied in various tissues of the chick.

2. Liver and kidneys were highly active in the hydrolysis of acetate, and showed only slight activity in the hydrolysis of palmitate or in the synthesis of vitamin A esters.

3. Pancreas was highly active in both acetate and palmitate hydrolysis and in the synthesis of vitamin A esters.

4. The small intestine showed a moderate and equal activity in all three reactions.

5. Sodium taurocholate enhanced the hydrolysis of vitamin A palmitate by pancreas and small intestine. It also enhanced the hydrolysis of vitamin A acetate by pancreas, but had no effect on the hydrolysis of acetate by liver, and even inhibited this reaction in kidneys and intestine. It also inhibited the synthesis of vitamin A esters by pancreas and small intestine.
\end{abstract}

Ganguly (1949) observed that pig pancreas homogenates incubated with vitamin A esters of fish-liver oil give rise to vitamin A alcohol. A few years later such an activity was demonstrated in rat liver homogenates (McGugan \& Laughland, 1952; Ganguly, 1954). Later Ganguly and his collaborators thoroughly investigated the distribution, properties and biological role of vitamin A esterase in different tissues. Seshadri Sastry, Krishnamurthy \& Ganguly (1957) showed that the liver enzyme is active in hydrolysing the esters of short-chain fatty acids such as the acetate, while enzymes from the pancreas, small intestine, spleen and kidneys are able to hydrolyse the esters of both short- and long-chain fatty acids. It was further stated that the liver contains three distinct enzymes for the hydrolysis of short-chain fatty acid esters of simple aliphatic alcohols, vitamin A alcohol and cholesterol (Seshadri Sastry \& Ganguly, 196I). The intestinal and pancreatic tissues, which were active on esters of vitamin A and cholesterol with both long- and short-chain fatty acia's, required, for the hydrolysis of the higher esters, the presence of bile salts (Mahadevan, Murthy, Krishnamurthy \& Ganguly, r96r). Both the intestine and the pancreas of rats possessed the capacity to synthesize vitamin A esters, while other tissues like liver, blood, spleen and kidneys had negligible activities (Mahadevan et al. 196r). Contrarily to their effect on hydrolysis, bile salts had an inhibitory effect on the synthesis of vitamin esters (Murthy, Mahadevan, Seshadri Sastray \& Ganguly, 196r). Most of the work referred to above was carried out with rat tissues. As a first step in an investigation on the effect of various factors on vitamin A absorption and utilization by chicks, we felt the need to acquire more information on the vitamin A esterase activity in different organs of this species. 


\section{EXPERIMENTAL}

Preparation of enzyme solutions. All organs were obtained from 2 to 4 -week-old New-Hampshire $\times$ White Leghorn chicks fed on a commercial diet. The small intestine was freed from its contents by thoroughly washing with a $0.9 \%$ solution of $\mathrm{NaCl}$. The tissues were homogenized in an Ultra Turrax homogenizer (Janke und Kunkel KG, Staufen i.Br.) in $0.25 \mathrm{M}$-sucrose solution added in amounts to obtain a concentration of $200 \mathrm{mg}$ fresh tissue per $\mathrm{ml}$ homogenate. Homogenization and further treatments were carried out while the homogenates were kept in ice-cold water. The homogenates were centrifuged at $8000 \mathrm{~g}$ for $10 \mathrm{~min}$ at $0^{\circ}$ in a Sorvall refrigerated centrifuge. The supernatant solutions thus obtained were used as enzyme preparations. When stored at $22^{\circ}$ for 20 days, these solutions showed either a small loss or no loss at all of enzymic activity: we concluded therefore that they can be safely used after a storage period of not more than 2 weeks. When the activity of blood plasma was investigated, the plasma was added to the medium with no further treatment.

Vitamin A solutions. Crystalline vitamin A acetate or palmitate (Hoffmann-La Roche and Co., Basle, Switzerland) was purified before use by passing through an alumina column. Vitamin A alcohol was prepared by saponification of crystalline vitamin $A$ acetate. The liberated alcohol was extracted with petroleum ether and further purified by chromatography on alumina. The vitamin, in its different forms, was dissolved either in ethanol, or in water by the following procedure: to a weighed amount of the vitamin (alcohol, acetate or palmitate) chloroform solutions of Tween 80 and tocopheryl acetate were added in amounts to give weight ratios between vitamin $A$, Tween 80 and tocopheryl acetate of $r: 10: 2$ respectively. The vitamin $A$ concentration of the chloroform solution was determined by the Carr-Price method and the chloroform was evaporated under reduced pressure. An appropriate amount of water was then added to bring the vitamin A to the desired concentration. According to our experience, such aqueous dispersions of vitamin $\mathrm{A}$ acetate, after 10 days storage at $22^{\circ}$, lose $10 \%$ of their content and the changes which accompany this decrease interfere with the activity of the enzyme solutions. All aqueous solutions were therefore stored under nitrogen at $-22^{\circ}$ and used when not more than I week old. To the vitamin A alcohol solution used in the esterification assays a mixture of stearic and palmitic acids, in the ratio $2: \mathrm{I}$, was added. As was shown by Pollard \& Bieri (1960) and by Murthy et al. (1961) vitamin A esterase seems to be relatively non-specific towards long-chain fatty acids.

Preparation of incubation media and of the enzymes. The incubations were carried out in $10 \mathrm{ml}$ centrifuge tubes with ground-glass stoppers: $2.8 \mathrm{ml}$ veronal buffer (Michaelis, 1931) of the appropriate $\mathrm{pH}$ and $\mathrm{O}^{\circ} \mathrm{I} \mathrm{ml}$ of the substrate solution were brought to temperature equilibrium during $10 \mathrm{~min}$ in a water bath at $37^{\circ}$, then $0.1 \mathrm{ml}$ enzyme solution was added. The additions of substrate or enzyme solutions were made with the help of a Lang Levy micropipette. The substrates were added in amounts of 220-300 i.u. if not stated otherwise. Hydrolysis was conducted at $\mathrm{pH} 8.6$ and esterification at $\mathrm{pH} 6.6$. These $\mathrm{pH}$ values were chosen in accordance with the findings of Seshadri Sastry \& Ganguly (1961) and Mahadevan et al. (1961). Incubation was 
stopped by the addition of $3 \mathrm{ml}$ absolute ethanol. All incubations were carried out in duplicate.

One of the factors which influence the level of activity found under the abovementioned conditions is the type of vitamin A solution (aqueous or ethanolic) used. Because of the lability of the aqueous solutions, we checked if it was possible to use ethanolic solutions of the vitamin, which are most stable. When vitamin A acetate was added to the medium dissolved in $0^{\circ} \mathrm{I} \mathrm{ml}$ ethanol, the hydrolytic activity of all tissues (liver, kidney, pancreas and intestine) was enhanced, particularly of liver and kidney.

Clearly Tween 80 has an inhibitory effect on vitamin A ester hydrolysis. There is a possibility that a different detergent may have no inhibitory effect and give even better results than the ethanolic solution. This possibility was tested in regard to Triton X-100, for which such a claim has been made by Mahadevan, Ayyoub \& Roels (1966) in their work on vitamin A palmitate hydrolase of rat liver. When this detergent was used in experiments on the hydrolysis of vitamin A palmitate by pancreas homogenates it did not have the inhibitory effect of Tween 80 , but the results were no better than those obtained with the ethanolic solution of the substrate.

Extraction of the vitamin from the media and separation of the alcohol and ester fractions. The vitamin was extracted by adding $5 \mathrm{ml}$ solvent and shaking for I min with a Vortex Genie shaker (Scientific Industries Inc., Queens Village, NY). After a light centrifugation, a sample of the solvent was transferred to an alumina column and the vitamin A alcohol and ester were separated by the method of Thompson, Ganguly \& Kon (I949). As extractant we used at first light petroleum (b.p. $60^{\circ}-80^{\circ}$ ), but it was found that for the extraction of vitamin A palmitate from media containing pancreas or intestine homogenates light petroleum is an inefficient solvent. Ethyl ether and chloroform were found to give complete extraction, and chloroform was used during most of the work here presented. Later on benzene was found to be equally satisfactory as an extractant and preferable for technical reasons (being the upper phase). When chloroform was used, $4 \mathrm{ml}$ were added, the tubes were then shaken during I min and lightly centrifuged. After centrifugation two phases were obtained: an upper waterethanol phase with a volume of $4 \mathrm{ml}$ and a lower chloroform-ethanol phase with a volume of $6 \mathrm{ml}$. Five $\mathrm{ml}$ of this phase were transferred, with the help of a $5 \mathrm{ml}$ syringe with a long needle, to a round flask and evaporated under reduced pressure. The residue was dissolved in $4 \mathrm{ml}$ light petroleum and chromatographed on alumina.

Vitamin A concentration was determined by the Carr-Price method.

\section{RESULTS}

Hydrolytic activity of different tissues and influence of bile on hydrolysis of vitamin $A$ acetate. The hydrolytic activity of liver, intestine, kidneys and pancreas homogenates on vitamin $A$ acetate added in water solution and the influence of bile on it were investigated. The bile was obtained from chick gall-bladder and diluted tenfold with the buffer: $0.5 \mathrm{ml}$ of this bile solution was added to the incubation medium instead of an equal volume of the buffer. The results are presented in Table I. Fresh bile greatly enhanced the activity of pancreas tissue but had no effect on that of other 
tissues. When the activities obtained with the system including bile were compared, liver, kidney and pancreas were seen to have activities of the same order, whereas that of the intestinal tissue was much lower. Blood plasma did not show any hydrolytic activity.

Synthetic activity of different tissues. In this experiment we determined the level of esterification of vitamin A alcohol by different tissues ('Table 2). Pancreas homogenates were by far the most active, in spite of the incomplete extraction of the ester caused by the use in this experiment of light petroleum as extractant. All other tissues used, namely liver, kidney, intestine and blood plasma, formed only very small amounts of ester.

Table I. Influence of bile on hydrolysis of vitamin $A$ acetate by homogenates of tissues of chicks

\begin{tabular}{lcc} 
& \multicolumn{2}{c}{ Substrate converted $(\%)^{*}$} \\
Tissue & Without bile & With bile \\
Liver & 55 & 55 \\
Kidney & 54 & $5 \mathrm{I}$ \\
Intestine & 9 & 9 \\
Pancreas & 9 & 53 \\
Plasma & $\circ$ & 0
\end{tabular}

* After deduction of the blank value.

Table 2. Esterification of vitamin $A$ alcohol by different tissues of chicks

$\begin{array}{lccc}\text { Tissue } & \text { i.u. } & \begin{array}{c}\text { As \% of } \\ \text { total amount } \\ \text { recovered }\end{array} & \begin{array}{c}\text { Total recovery } \\ \text { (alcohol + ester) }\end{array} \\ \text { Liver } & 3 & 1 \% 4 & 99 \\ \text { Kidney } & 3 & 1 \cdot 4 & 100 \\ \text { Intestine } & 3 & 1 \cdot 4 & 99 \\ \text { Pancreas } & 4 * & 2 \cdot 0 & 98 \\ \text { Plasma } & 40 & 24 \cdot 4 & 78 \\ & 44^{*} & 27 \cdot 5 & 76\end{array}$

* This replicate was carried out on the same homogenate 2 days after the first determination.

Influence of sodium taurocholate on the hydrolytic and synthetic activities of different tissues. In Table I it was shown that bile enhanced the hydrolysis of vitamin A acetate by pancreas homogenates, but had no effect on other tissues. In these assays the effect of sodium taurocholate on the hydrolysis of vitamin A acetate and palmitate by liver, kidneys and pancreas homogenates and on the esterification of vitamin $\mathrm{A}$ alcohol by pancreas and intestine homogenates was investigated. The reactions were carried out with tissues taken from two 22-day-old chicks. The values presented in Table 3 show that sodium taurocholate influenced strongly only the activity of the pancreatic tissue. This influence had an opposite trend when the two directions of the reaction, i.e. the hydrolysis and the esterification, were tested. Whereas hydrolysis of vitamin A acetate 
or palmitate was equally raised by sodium taurocholate, this salt inhibited the esterification of the alcohol by pancreas homogenates. Hydrolysis of vitamin A acetate by liver tissue was not influenced by this factor. There was a clear inhibitory effect of sodium taurocholate on the hydrolysis of vitamin A acetate by kidneys or intestine. This finding contrasts with the lack of influence of bile on this reaction as previously found. Though no satisfactory explanation can be offered for this contradiction, it must be pointed out that the amount of bile salt added as sodium taurocholate $(30 \mathrm{mg})$ was much greater than the amount added as bile.

Table 3. Influence of sodium taurocholate on the hydrolysis and synthesis of vitamin $A$ ester by different tissues of chicks

\begin{tabular}{|c|c|c|c|c|}
\hline \multirow[b]{2}{*}{ Tissue } & \multirow[b]{2}{*}{$\begin{array}{c}\text { Sodium } \\
\text { taurocholate }\end{array}$} & \multicolumn{2}{|c|}{ Hydrolysis of: } & \multirow[b]{2}{*}{$\begin{array}{c}\text { Synthesis of } \\
\text { vitamin A } \\
\text { ester } \\
(\%)^{*}\end{array}$} \\
\hline & & $\begin{array}{c}\text { Vitamin A } \\
\text { acetate } \\
(\%)^{*}\end{array}$ & $\begin{array}{c}\text { Vitamin A } \\
\text { palmitate } \\
(\%)^{*}\end{array}$ & \\
\hline \multirow[t]{2}{*}{ Liver } & + & 87 & 2 & - \\
\hline & - & 85 & 3 & - \\
\hline \multirow[t]{2}{*}{ Kidney } & + & 40 & 4 & 一 \\
\hline & - & 69 & 3 & 一 \\
\hline \multirow[t]{2}{*}{ Intestine } & + & 8 & 6 & 2 \\
\hline & - & 14 & 3 & 2 \\
\hline \multirow[t]{2}{*}{ Pancreas } & + & 96 & $95 t$ & 8 \\
\hline & - & 13 & $4 \dagger$ & 28 \\
\hline
\end{tabular}

Table 4. Hydrolysis of vitamin $A$ palmitate and esterification of vitamin $A$ alcohol by different tissues of chicks, and their variability

(Mean values and their standard errors for tissues obtained from six 22-day-old chicks)

\begin{tabular}{|c|c|c|c|c|c|c|}
\hline \multirow[b]{2}{*}{ Tissue } & \multicolumn{3}{|c|}{ Hydrolysis $(\%)$} & \multicolumn{3}{|c|}{ Esterification (\%) } \\
\hline & Value & SE & $\mathrm{CV}$ & Value & SE & $\mathrm{CV}$ \\
\hline Liver & 0.9 & $0 . \mathrm{I}$ & 18 & $I \cdot 7$ & 0.2 & 24 \\
\hline Kidney & $4^{\circ} 0$ & 0.6 & 33 & $I \cdot 4$ & 0.1 & I4 \\
\hline Duodenal mucosa & $10 \cdot 3$ & 3.0 & 69 & $2 \cdot 3$ & 0.5 & 52 \\
\hline Pancreas & $96 \cdot 0$ & $I \cdot 0$ & 2 & $36 \cdot 0$ & $2 \cdot 6$ & I7 \\
\hline
\end{tabular}

$\mathrm{cv}$, coefficient of variation.

Variability of the enzymic activities in individual chicks. In the assays here presented we intended to determine the degree of variability of the enzymic activities in the tissues of individual chicks. Since in the previous assays the activity of whole intestine homogenates was found to be quite low, in the present ones we tested whether the activity of the duodenal mucosa was higher. Each system was tested in tissues obtained from six 22-day-old chicks. In the determination of hydrolytic activity, vitamin A palmitate was used as substrate and sodium taurocholate was included in the systems. The results given in Table 4 show that duodenal mucosa was more active for the hydrolysis of vitamin A palmitate than whole intestine homogenates. 
The esterifying activity of this tissue was similar to that of the whole intestine homogenate. The hydrolytic and synthetic activities of the other tissues were quite similar to those found in the previous experiments. The individual variability of these enzymic activities, as reflected in their coefficients of variation, was moderate in most tissues, and quite high only in the duodenal mucosa. However, in results obtained later on (unpublished observations), coefficients of variation were approximately 13 even in this tissue. The analysis of tissues from five to six birds seems therefore to be enough when these activities are to be estimated in chicks.

\section{DISCUSSION}

Optimal conditions for the activity of the hydrolysing enzymes from the different organs of the chick differ. These conditions were found to include, for pancreas, the presence of bile or bile salts, which had a dramatic effect on the hydrolysis of both ester forms used but especially on the palmitate, raising its hydrolysis from negligible to almost complete. The addition of sodium taurocholate to the medium for the test of vitamin A acetate hydrolysing activity had quite a different effect in the different tissues: very strong enhancement of activity in pancreas, depression of activity in duodenal mucosa and kidney, and no effect on liver. These differences support the assumption that there is more than one enzyme involved in this reaction in the different organs.

According to Mahadevan et al. (1961), Tween 20 inhibited somewhat the hydrolysis of vitamin A acetate by rat intestinal mucosa, but only when added to the medium in high amounts $(5 \mathrm{mg} / \mathrm{ml})$, whereas the hydrolysis of vitamin A palmitate was inhibited even at the level of $2 \mathrm{mg} / \mathrm{ml}$. Tween 80 has shown a much stronger inhibitory power against the hydrolysis of the acetate by all the four tissues tested by us: even in the very low concentration used $(0.8-0.4 \mathrm{mg} / \mathrm{ml})$ there was an inhibition of about $30 \%$. The detergent Triton X-Ioo did not display the inhibitory effect shown by Tween 80; however, its use had no advantage over the use of ethanolic solutions of the substrate. Hence the inhibitory effect of ethanol on vitamin A palmitate hydrolase of rat liver found by Mahadevan et al. (1966) may have been linked to some specific differences between the different enzymes, but may also have been caused by the relatively high concentration of ethanol used by these authors in their system (10\% as against $3.3 \%$ in ours).

The incomplete extraction of vitamin A palmitate by light petroleum from the media even after denaturation with ethanol shows that long-chain fatty acid esters become bound to some fraction, which apparently is not protein, but could well be a lipoprotein. Stronger extractants, such as ethyl ether, chloroform, or benzene, must be used for a full extraction of these esters. This point seems to have been overlooked by some previous authors, and must be taken into consideration in order to avoid bias in any study of vitamin A esterase.

A strong hydrolysing activity of rat liver on vitamin A acetate has been known already for years (McGugan \& Laughland, I952; Ganguly \& Deuel, 1953; Ganguly, 1954). Seshadri Sastry et al. (1957) found that rat liver homogenates are highly active 
in hydrolysing esters of short-chain fatty acids but do not show any activity against esters of long-chain fatty acids. Our results show that chick liver homogenates display both activities, even if at quite different levels, the hydrolysis of vitamin A acetate being thirty times more efficient than the hydrolysis of the palmitate. These results are in accordance with the latest findings of Mahadevan et al. (1966), who also found that rat liver could hydrolyse both vitamin A acetate and palmitate. In addition, they found that the hydrolysing activity for acetate was localized in the microsomes fraction, whereas that for palmitate was localized in the nuclei and in a mitochondrial lysosome-rich fraction. This difference in localization constitutes another indirect proof that indeed two different enzymes are concerned.

Kidney homogenates from chicks had activities similar to those shown by the liver. In the intestine and pancreas homogenates, hydrolysing activities for both acetate and palmitate were present; in each organ they were of the same intensity, but in the pancreas the activities were much greater than in the intestine.

A comparison of our results with those of Seshadri Sastry et al. (1957) and those of Krishnamurthy, Seshadri Sastry \& Ganguly (1958), obtained with rats under similar conditions, shows that homogenates of liver and kidney from chicks are more active than those from rats in hydrolysing vitamin A acetate. A similar comparison with the results of Mahadevan et al. (I96r) shows that intestinal mucosa and pancreas homogenates of chicks have a much higher hydrolysing and esterifying power than those of rats. These levels of vitamin A esterase activity seem to be higher in the chick than in the rat, not only in some specific organ but as a whole: this could well be a species difference, connected perhaps with the higher requirement of the chick for vitamin $\mathrm{A}$.

The authors wish to thank Hoffmann-La Roche and Co, Basle, for the gift of pure vitamin $\mathrm{A}$ alcohol, acetate and palmitate.

This work was financed by grant FG-Is-135 from the United States Department of Agriculture.

\section{REFERENCES}

Ganguly, J. (I949). Some aspects of the metabolism of carotenoids and vitamin A. PhD Thesis, University of Reading.

Ganguly, J. (1954). Archs Biochem. Biophys. 52, 186.

Ganguly, J. \& Deuel, H. J., Jr. (1953). Nature, Lond. I72, I 20.

Krishnamurthy, S., Seshadri Sastry, P. \& Ganguly, J. (I958). Archs Biochem. Biophys. 75, 6.

McGugan, W. A. \& Laughland, D. H. (1952). Archs Biochem. Biophys. 35, 428.

Mahadevan, S., Ayyoub, N. I. \& Roels, O. A. (I966). F. biol. Chem. 24I, 57.

Mahadevan, S., Murthy, S. K., Krishnamurthy, S. \& Ganguly, J. (196I). Biochem. 7. 79, 416.

Michaelis, L. (193 I). Biochem. Z. 234, 139.

Murthy, S. K., Mahadevan, S., Seshadri Sastry, P. \& Ganguly, J. (I96r). Nature, Lond. 189, 482.

Pollard, C. J. \& Bieri, J. G. (1960). Archs Biochem. Biophys. 87, 9.

Seshardi Sastry, P. \& Ganguly, J. (I96x). Biochem. F. 8o, 397.

Seshadri Sastry, P., Krishnamurthy, S. \& Ganguly, J. (1957). Indian f. med. Res. 45, 263.

Thompson, S. Y., Ganguly, J. \& Kon, S. K. (1949). Br. F. Nutr. 3, 5o. 